KOŚCIÓŁ I PRAWO 8(21) 2019, nr 2, s. 87-103

DOI: http://dx.doi.org/10.18290/kip.2019.8.2-5

\author{
Piotr Fiałek
}

\title{
ZDATNOŚĆ DO ŚWIĘCEŃ I PRZYGOTOWANIE DO KAPŁAŃSTWA WEDŁUG KODEKSU PRAWA KANONICZNEGO Z 1983 ROKU I RATIO FUNDAMENTALIS INSTITUTIONIS SACERDOTALISZ 2016 ROKU
}

Kościół, prosząc Ducha Świętego o nowe powołania kapłańskie, wypełnia wezwanie Chrystusa ${ }^{1}$. Coraz bardziej aktualne staje się wołanie o kapłanów, którzy przyniosą światu nadzieję skierowaną ku Chrystusowi i właściwe wzorce moralne, bez których nie można przylgnąć do źródła łaski uświęcającej².

Kapłan może umacniać swoją tożsamość tylko w zjednoczeniu z Chrystusem. Mając świadomość niezasłużonego daru wybrania, powinien jednocześnie pamiętać o czuwaniu nad sobą. Moc Ducha Świętego stanowi gwarancję aktów sakramentalnych sprawowanych przez kapłana. Jednak

Ks. MGR LIC. PIOTR FIAŁEK - doktorant, Katedra Kościelnego Prawa Procesowego, Małżeńskiego i Karnego oraz Katolickich Kościołów Wschodnich, Instytut Prawa Kanonicznego, Wydział Prawa, Prawa Kanonicznego i Administracji Katolickiego Uniwersytetu Lubelskiego Jana Pawła II; adres do korespondencji: ul. Brata Alberta 2a, 14-202 Iława, Polska; e-mail: kspiotrf@gmail.com; https://orcid.org/0000-0001-5647-8810

${ }^{1}$ Ioannes Paulus PP. II, Adhortatio apostolica postsynodalis de Sacerdotum formatione in aetatis nostrae rerum condicione Pastores dabo vobis (25.03.1992), AAS 84 (1992), s. 657-804; tekst polski w: Adhortacje apostolskie Ojca Świętego Jana Pawła II. T. 1: 1979-1995, Wydawnictwo Znak, Kraków 2006 [dalej cyt.: PDV], nr 38.

${ }^{2}$ Tenże, Litterae encyclicae cunctis catholicae Ecclesiae de quibusdam quaestionibus fundamentalibus doctrinae moralis Ecclesiae Veritatis splendor (6.08.1993), AAS 85 (1993), s. 1133-228 [dalej cyt.: VS]; tekst polski w: Nauczanie Kościoła Katolickiego wersja 1.1 - program komputerowy, Wydawnictwo „M”, Kraków 2003, nr 3. 


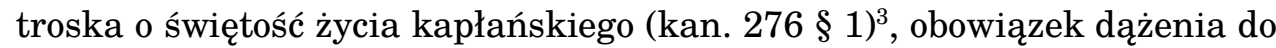
pełni życia chrześcijańskiego $\mathrm{w}$ wypełnianiu powierzonego zadania, spoczywa na konkretnej osobie [Pérez 2018, 101-102].

Papież Franciszek podejmuje pasterską troskę o Kościół poprzez zastosowanie właściwych norm i procedur mających na celu ochronę osób zagrożonych bądź dotkniętych złem, także nadużyciami w sferze seksualnej. Ponadto Biskup Rzymu przynosi słowo umocnienia tym, którzy wiernie wypełniają swoje powołanie ${ }^{4}$.

Troska o wszystkich ludzi, żywa i permanentna, w Kościele realizuje się nie tylko przez pomoc ofiarom nadużyć, lecz także staje się owocna w prawidłowym przygotowaniu do kapłaństwa. Prawo wiernych do opieki duszpasterskiej (kan. 213) oraz potrzeba autentycznego świadectwa o Chrystusie, są wypełnione przez Kościół także poprzez właściwą formację do kapłaństwa tych, których prawo Kościoła uznaje za zdatnych (kan. 232).

Celem niniejszego artykułu jest wskazanie przepisów prawa kanonicznego (zawartych w KPK/83), które regulują kwestię zdatności do kapłaństwa oraz przebieg formacji początkowej według nowego Ratio fundamentalis institutionis sacerdotalis ${ }^{5}$.

\section{1. ŚWIĘCENIA}

Święcenia są jednym z sakramentów pozostających w służbie komunii. Są nastawione na zbawienie innych, a temu, który otrzymał szczególną konsekrację do służby innym, pomagają w przyjęciu i wypełnieniu zbawienia

${ }^{3}$ Codex Iuris Canonici auctoritate Ioannis Pauli PP. II promulgatus (25.01.1983), AAS 75 (1983), pars II, s. 1-317; tekst polski w: Kodeks Prawa Kanonicznego, przekład polski zatwierdzony przez Konferencję Episkopatu, Pallottinum, Poznań 1984 [dalej cyt.: KPK/83].

${ }^{4}$ Francesco PP., Incontro La protezione dei minori nella Chiesa. /Vaticano, 21-24 febbraio 2019]. Discorso del Santo Padre Francesco al termine della concelebrazione eucaristica (24.02.2019), http://w2.vatican.va/content/francesco/pl/speeches/2019/february /documents/papa-francesco_20190224_incontro-protezioneminori-chiusura.html [dostęp: 18.05.2019].

${ }^{5}$ Congregazione per il Clero, Il dono della vocazione sacerdotale. Dar powołania do kapłaństwa. Ratio fundamentalis institutionis sacerdotalis (8.12.2016), Libreria Editrice Vaticana, Città del Vaticano 2016 [dalej cyt.: RFIS]. 
osobistego. Sakrament ten wprowadza w szczególne posłanie do służby w Kościele, aby budować Lud Boży ${ }^{6}$.

W kan. 1008 KPK/83 ustawodawca podaje definicję sakramentu święceń, w której proklamuje prawdę teologiczną o ich pochodzeniu Bożym [Krukowski 2011, 207-208]. W przepisie tym podkreślono, że ci, którzy otrzymali sakrament święceń, mają nowy tytuł, który zobowiązuje ich i zarazem uprawnia do szczególnej służby w Kościele. Na wzór Chrystusa wyświęceni są posłani, aby budować Lud Boży, wypełniając swoje posłannictwo zgodnie ze stopniem święceń, jaki otrzymali7. W kan. $1009 \S 3$ ustawodawca wskazuje: „Ci, którzy zostali ustanowieni biskupami lub prezbiterami, otrzymują misję i władzę działania w osobie ChrystusaGłowy, natomiast diakoni zostają ustanowieni po to, by służyli ludowi Bożemu poprzez diakonię liturgii, słowa i miłości”. Kan. 1008 i 1009 zostały zmienione na mocy motu proprio Omnium in mentem papieża Benedykta $\mathrm{XVI}^{8}$. Doprecyzowanie zawarte w kan. 1009 § 3 wyraża różnice, jakie występują między wyświęconymi. Biskupstwo i prezbiterat są stopniami kapłaństwa urzędowego, podczas gdy diakonat jest stopniem święceń, ale nie jest stopniem kapłaństwa urzędowego [Krukowski 2011, 207-208]. Prezbiterat i episkopat różnią się od diakonatu co do istoty. Między wyświęconymi w stopniu episkopatu i w stopniu prezbiteratu nie ma różnicy co do istoty. Są oni rzeczywistymi kapłanami Chrystusa. Biskupi otrzymują kapłaństwo w stopniu pełnym, natomiast prezbiterzy nie posiadają szczytu kapłaństwa, są zaś współpracownikami biskupów. Nie ma tu różnicy co do istoty, ale co do stopnia [Pastuszko 2008, 39-40]. Diakoni zaś pozostają w kapłaństwie wspólnym, jednak nie należą do wiernych świeckich, lecz mają udział w diakonii liturgii, słowa i miłości. Przedmiotem niniejszego opracowania jest sakrament święceń w drodze do kapłaństwa urzędowego, dlatego też nie podjęto omówienia diakonatu stałego. Należy

\footnotetext{
${ }^{6}$ Catechismus Catholicae Ecclesiae, Libreria Editrice Vaticana, Città del Vaticano 1997; tekst polski w: Katechizm Kościoła Katolickiego, Pallottinum, Poznań 2002 [dalej cyt.: KKK], nr 1534-1535.

${ }^{7}$ Zob. Sacrosanctum Concilium Oecumenicum Vaticanum II, Constitutio dogmatica de Ecclesia Lumen gentium (21.11.1964), AAS 57 (1964), s. 5-75 [dalej cyt.: LG]; tekst polski w: Sobór Watykański II, Konstytucje, dekrety, deklaracje. Tekst polski. Nowe tłumaczenie, Pallottinum, Poznań 2002, s. 104-66 [dalej cyt.: LG], nr 8.

${ }^{8}$ Benedictus PP. XVI, Litterae apostolicae motu proprio datae quaedam in Codice Iuris Canonici immutantur Omnium in mentem (26.10.2009), AAS 102 (2010), s. 8-10; tekst polski w: „L’Osservatore Romano” (wyd. pol.) 5 (333) 2010, s. 13-14.
} 
jednak zaznaczyć, iż diakonat stały został przywrócony jako pierwszy stopień hierarchii święceń (LG 29).

\section{WYMOGI STAWIANE KANDYDATOM DO ŚWIĘCEŃ}

Z woli Chrystusa Apostołami zostali ci, których on sam wezwał i wybrał. Chrystus wybrał mężczyzn, aby uczynić z nich kolegium Dwunastu Apostołów. Działanie Jezusa podjęli Apostołowie i na wzór Chrystusa wybierali spośród mężczyzn swoich współpracowników. To samo czyni Kolegium Biskupów, aktualizując kolegium Dwunastu aż do paruzji. Kościół pozostaje wierny wyborowi dokonanemu przez Chrystusa (KKK 1577).

Nauka Kościoła co do zdatności do święceń została proklamowana przez ustawodawcę w kan. 1024. Określono w nim, iż święcenia ważnie przyjmuje tylko mężczyzna, który został już ochrzczony. Konieczność chrztu przed przyjęciem innych sakramentów została wyrażona także w kan. 842. Stanowi on bramę pozostałych sakramentów. Musi być udzielony z zastosowaniem właściwej formy słownej przy obmyciu w prawdziwej wodzie (kan. 849).

W kan. 1024 zawarto normę wywodzącą się z prawa Bożego, zgodnie z którą święcenia ważnie przyjmuje tylko mężczyzna. Nie występuje tu wątpliwość doktrynalna [Skorupa 2011, 88]. Zgodnie z treścią deklaracji Inter insigniores wydanej przez Kongregację Nauki Wiary w sprawie dopuszczania kobiet do kapłaństwa urzędowego: „...) Kościól, pragnąc pozostać wierny przykładowi Pana uważa, że nie jest upoważniony, by dopuścić kobiety do Święceń kapłańskich". W liście apostolskim Ordinatio sacerdotalis Jan Paweł II potwierdził tę naukę, przywołując niezmienną praktykę Kościoła. Zwrócił także uwagę na starania papieża Pawła VI w dogłębnym wyjaśnieniu i przedstawieniu nauki o braku możliwości święcenia kobiet ${ }^{10}$. Jest to doktryna oparta na słowie Bożym niezmiennie zachowywana w Tradycji Kościoła ${ }^{11}$.

\footnotetext{
${ }^{9}$ Sacra Congregatio pro Doctrina Fidei, Declaratio circa quaestionem admissionis mulierum ad sacerdotium ministeriale Inter insigniores (15.10.1976), AAS 69 (1977), s. 98-116; tekst polski w: W trosce o pełnie wiary. Dokumenty Kongregacji Nauki Wiary 1966-1994, red. Z. Zimowski, J. Królikowski, Wydawnictwo Diecezji Tarnowskiej Biblos, Tarnów 2010, s. 134.

${ }^{10}$ Ioannes Paulus PP. II, Epistola apostolica de sacerdotali ordinatione viris tantum reservanda Ordinatio Sacerdotalis (22.05.1994), AAS 86 (1994), s. 545-48; tekst polski
} 
W trosce o zachowanie depozytu wiary Kościół chroni zasadę święceń mężczyzn wprowadzoną wolą Chrystusa, co deklaruje w kan. 1024. Usiłowanie udzielenia święceń kobiecie jest przestępstwem [Stokłosa 2015, 11314]. Jest ono zagrożone karą ekskomuniki latae sententiae, a w przypadku duchownego możliwe jest także wydalenie ze stanu duchownego ${ }^{12}$.

Warunki ważności święceń określono w kan. 1024. Co do godziwości ustawodawca odnosi się w kolejnym kanonie. Regulacja ta dotyczy sakramentu święceń w stopniach diakonatu i prezbiteratu, ale nie obejmuje episkopatu [Pastuszko 2001, 106]. Kan. $1025 \S 1$ stanowi, że kandydat do święceń prezbiteratu powinien przejść stosowną próbę, o której jest mowa w kan. 1032 § 2 . Próba ta ma odbywać się po zakończeniu studiów filozoficzno-teologicznych (kan. $1032 \S 1$ ). Diakon nie może odmówić podjęcia takiej próby [tamże, 107].

Ocenie Kościoła poddane zostają także przymioty, jakimi powinien odznaczać się kandydat do święceń. W kan. 1029 ustawodawca wskazał na określone aspekty, które powinny zostać zweryfikowane w obiektywnej ocenie całokształtu osoby kandydata. Kan. 1029 stanowi wskazanie, iż na kompetentnym przełożonym spoczywa obowiązek rozeznania powołania u poszczególnych kandydatów. To kompetentny przełożony dopuszcza kandydata do święceń, po uprzednim zbadaniu jego zdatności. „Dopuszczenie to nie może być oparte wyłącznie na subiektywnych kryteriach. Ewentualne wyświęcenie nieodpowiedniego kandydata nie jest skutkiem skierowanej przez niego prośby, ale dopuszczenia przez przełożonego osoby nieodpowiedniej" [Skorupa 2011, 88].

Według obszarów wskazanych przez ustawodawcę w kan. 1029 kandydat do święceń powinien zachowywać nieskażoną wiarę. Ma być wolny od herezji, a zatem ma przyjmować wszystkie prawdy wiary, które Kościół podaje do wierzenia. Nie może być apostatą ani schizmatykiem (kan. 751). Ponadto kandydat musi kierować się prawidłową intencją, czyli wolą

w: Prawo sakramentów. Wybór źródeł Kościoła łacińskiego, red. E. Szczot, D. Kwiatkowski, W. Lech, Wydawnictwo KUL, Lublin 2017, s. 843-46.

${ }^{11}$ Congregatio pro Doctrina Fidei, Responsum ad dubium circa doctrinam in Epist. Ap. «Ordinatio Sacerdotalis» traditam (28.10.1995), AAS 87 (1995), s. 1114; tekst polski w: W trosce o pelnie wiary. Dokumenty Kongregacji Nauki Wiary 1995-2000, red. J. Królikowski, Z. Zimowski, Wydawnictwo Diecezji Tarnowskiej Biblos, Tarnów 2002, s. 13.

${ }^{12}$ Congregatio pro Doctrina Fidei, Normae de gravioribus delictis (21.05.2010), AAS 102 (2010), s. 419-30; tekst polski w: „L’Osservatore Romano” (wyd. pol.) 10 (326) 2010, s. 53-59. 
służenia Bogu i Kościołowi [Pastuszko 2008, 235]. W kan. 1026 zawarto wymóg, by kandydat do święceń przyjmował je w sposób wolny. Każdy wierny ma prawo do swobodnego wyboru powołania (kan. 219). Jest to fundamentalne prawo każdego chrześcijanina [Gosiewski 2017, 224]. Nie można zatem przymuszać do przyjęcia święceń ani odwodzić od nich kanonicznie zdatnych. Jeśli właściwy przełożony postąpiłby wbrew wymienionym kanonom, wówczas mógłby dopuścić się przestępstwa nadużycia władzy przewidzianego przez ustawodawcę w kan. $1389 \S 1$.

Od kandydatów do święceń należy także wymagać, aby wykazali się należytą wiedzą, zweryfikowaną przez egzaminy, dobrą opinią pozyskaną ze środowiska, które jest zdolne do oceny obyczajów kandydata, a także odpowiednim poziomem zdrowia fizycznego i psychicznego. Wymienione obszary mają być zweryfikowane w trakcie formacji seminaryjnej.

\section{NIEPRAWIDŁOWOŚCI I PRZESZKODY}

W tytule VI, rozdziale III Księgi IV KPK/83 ustawodawca stanowi, iż kandydat do święceń powinien być wolny od nieprawidłowości i przeszkód. Traktuje o tym art. 3, w kan. 1040-1049. Wśród tych zagadnień trzeba również poruszyć kwestie związane $\mathrm{z}$ tendencjami homoseksualnymi, a także chorobami w postaci alkoholizmu i celiakii. Na wstępie jednak zaznacza się, iż można podlegać jedynie tym przeszkodom i nieprawidłowościom, które ustawodawca wymienia w KPK/83 (kan. 1040).

Nieprawidłowość do święceń ma charakter stały, co skutkuje zakazem przyjmowania oraz wykonywania święceń. Przeszkoda, w odróżnieniu do nieprawidłowości, jest czasowa. Powoduje jednak te same skutki, co nieprawidłowość [Janczewski 2014, 238]. Ustawodawca zabrania przyjmowania święceń w przypadku istnienia nieprawidłowości oraz przeszkód. Święcenia będą jednak ważne nawet wtedy, gdyby ktoś złamał wspomniany zakaz. Ustawodawca wskazuje na takie rozumienie w kan. $1044 \S 1,1^{\circ}$ i $\S 2,1^{\circ}$.

Nieprawidłowości zostały wyliczone w kan. $1041,1^{\circ}-6^{\circ}$. Są nimi: amencja lub inna choroba psychiczna występująca w momencie święceń, przestępstwo apostazji, schizmy, herezji, usiłowanie zawarcia małżeństwa, zabójstwo człowieka popełnione dobrowolnie, przestępstwo aborcji po zaistnieniu skutku, okaleczenie kogoś lub siebie, podjęcie próby samobójczej, 
wykonanie aktów władzy święceń nie mając odpowiednich święceń [Krukowski 2011, 238-39].

Przeszkody określono w kan. 1042, $1^{\circ}-3^{\circ}$. Są nimi: ważny węzeł małżeński (przeszkoda nie dotyczy kandydatów do diakonatu stałego), wykonywanie urzędu lub zarządu zakazanego dla osób duchownych, brak utwierdzenia w wierze (dotyczy neofitów).

W czerwcu 1995 r. Kongregacja Nauki Wiary wydała dokument, w którym stwierdza, że nie mogą być dopuszczeni do święceń ci kandydaci, którzy są chorzy na celiakię, są dotknięci chorobą alkoholową lub podobnymi schorzeniami ${ }^{13}$. W niektórych przypadkach chorzy na celiakię będą mogli być dopuszczeni do święceń, o ile dany kandydat będzie mógł przyjmować hostię z niską zawartością glutenu, a okoliczności, zdaniem kompetentnej władzy, będą świadczyć o konieczności wyświęcenia danej osoby ze względu na dobro dusz [Adamczyk 2013, 92].

Święceń nie można udzielić także osobom, które są aktywnymi homoseksualistami, mają głęboko zakorzenione tendencje homoseksualne lub popierają kulturę gejowską ${ }^{14}$. Nikt nie może domagać się przyjęcia do seminarium ani też udzielenia święceń (KKK 1578), zwłaszcza gdy dotyka go tak poważne zaburzenie.

\section{FORMACJA DO KAPŁAŃSTWA WEDEUG RATIO FUNDAMENTALIS INSTITUTIONIS SACERDOTALIS}

W dekrecie o formacji kapłańskiej Optatam totius ${ }^{15}$ wskazano, iż wyższe seminaria duchowne są konieczne dla formacji kapłańskiej (nr 4). Ma ona przebiegać jako formacja ludzka, duchowa, intelektualna i duszpasterska $^{16}$.

${ }^{13}$ Congregazione per la Dottrina della Fede, Lettera a tutti i Presidenti delle Conferenze Episcopali sull'uso del pane con poca quantità di glutine e del mosto come materia eucaristica (19.06.1995), III. D. „Notitiae” 31 (1995), s. 608-10.

${ }^{14}$ Congregazione per L'Educazione Cattolica, Istruzione circa i criteri di discernimento vocazionale riguardo alle persone con tendenze omosessuali in vista della loro ammissione al Seminario e agli Ordini sacri (4.11.2005), AAS 97 (2005), s. 1007-1013.

${ }^{15}$ Sacrosanctum Concilium Oecumenicum Vaticanum II, Decretum de institutione sacerdotali Optatam totius (28.10.1965), AAS 58 (1966), s. 713-27 [dalej cyt.: OT]; tekst polski w: Sobór Watykański II, Konstytucje, s. 288-301.

${ }^{16}$ Papież Jan Paweł II w PDV określił wymiary formacji kapłańskiej, stosując następujące tytuły: „formacja ludzka fundamentem całej formacji kapłańskiej” (43-44); 
Kościół ma więc obowiązek formacji [Pastuszko 2008, 266-67]. Ustawodawca wyraża to w kan. 232. Wypełnia go m.in. poprzez przestrzeganie norm wyrażonych w kan. 242 i 243. Stanowią one, iż formacja do kapłaństwa jest regulowana prawem powszechnym, jak i partykularnym. Prawo powszechne $\mathrm{w}$ tej materii to przepisy KPK/83 oraz RFIS. Prawo partykularne musi być zgodne z prawem powszechnym oraz uregulowane na podstawie dyspozycji zawartych w kan. $242 \S 1$, wedle których konferencja biskupów danego kraju powinna opracować program formacji kapłańskiej, uwzględniając w nim normy wydane przez Stolicę Apostolską, aby dostosować formację do warunków regionalnych - adaptacja powinna być uznana przez Stolicę Apostolską. Konferencja Episkopatu Polski wydała „Zasady formacji kapłańskiej w Polsce”17. Zatwierdziła je Kongregacja Wychowania Katolickiego w dniu 26 sierpnia 1999 r. Obecnie Komisja Duchowieństwa przy Konferencji Episkopatu Polski opracowuje wytyczne dostosowane do RFIS ${ }^{18}$. Prawo partykularne to także własny regulamin każdego seminarium zatwierdzony przez biskupa i dostosowany do krajowych programów kształcenia kapłanów (kan. 243).

Wydane w 2016 r. RFIS ujmuje formację kapłanów jako trwającą nieustannie. Formacja ta musi wdrażać kandydatów do kapłaństwa poprzez kolejne etapy, budujące stopniowo osobę duchowną. Jest to zagadnienie istotne, zwłaszcza wobec zjawisk społecznych, które dokonują się we współczesnym świecie. Zjawiska te dotyczą także pojmowania kapłaństwa i osoby kapłana. Jako nieprawidłowe można wskazać postrzeganie kapłaństwa jako specyficznej funkcji, która ma dokonywać się jedynie w wymiarze doczesnym lub jako reprezentanta instytucji przeznaczonej do działalności charytatywnej, czy też pracownika organizacji kościelnej delegowanego przez daną wspólnotę, aby zapewnił jej właściwe funkcjonowanie [Selejdak 2017, 104]. Kongregacja ds. Duchowieństwa wskazała, że problemy w błędnym rozumieniu kapłaństwa są obecne także w różnych wspólnotach

\footnotetext{
„formacja duchowa: zjednoczenie z Bogiem i poszukiwanie Chrystusa” (45-50); „formacja intelektualna: zrozumienie wiary” (51-56); „formacja duszpasterska: udział w miłości Jezusa Chrystusa Dobrego Pasterza” (57-59).

${ }^{17}$ Konferencja Episkopatu Polski, Ratio institutionis sacerdotalis pro Polonia. Zasady formacji kapłańskiej w Polsce (28.09.1999), Kuria Metropolitalna-Tygodnik Katolicki „Niedziela”, Częstochowa 1999.

${ }^{18}$ Szerzej zob. https://episkopat.pl/trwaja-prace-nad-dokumentem-o-formacji-seminaryj nej/ [dostęp: 23.05.2019].
} 
kościelnych, a bierze się to z niewłaściwego rozróżnienia przez wiernych istoty kapłaństwa wspólnego od istoty kapłaństwa urzędowego ${ }^{19}$.

W kontekście pojmowania kapłaństwa przez wiernych, spośród których wywodzą się przyszli kapłani [Gerosa 1999, 250] warto wspomnieć badania, jakie przeprowadził K. Pawlina wśród młodzieży. Obraz kapłana w oczach ludzi młodych (stan na 2008 r.) był pozytywny. Kapłan, zdaniem respondentów, to człowiek, który uczy o Bogu, pomaga, odprawia Mszę św. i inne sakramenty. Jest jednak naznaczony słabościami, które są trudne do przyjęcia przez młodych. Nie mogą także zrozumieć wyrzeczenia w postaci celibatu. Dostrzegają niewłaściwe relacje między kapłanami [Pawlina 2008, 22].

RFIS wychodzi naprzeciw tym problemom, dając wytyczne dla formacji początkowej i permanentnej jako integralnej wizji obejmującej wymiary formacyjne przyjęte na podstawie PDV (RFIS 3). Przywołuje postawę ucznia Chrystusa, zarówno na etapie seminarium, jak i w kapłaństwie, wskazując, iż najlepszym środowiskiem formacyjnym jest wspólnota. Po raz pierwszy wprowadza nazwy poszczególnych etapów formacji początkowej [Puchalski 2018, 427].

Pierwszym z etapów formacji początkowej jest „etap propedeutyczny” (RFIS 57). Powinien on trwać nie mniej niż jeden rok i nie dłużej niż dwa lata. Już na tym etapie w osobie alumna ma dokonywać się weryfikacja, czy rzeczywiście pragnie kontynuować formację do kapłaństwa, czy też odkrywa w sobie powołanie na innej drodze życia. Będzie to możliwe w oparciu się na mocnym fundamencie duchowym i pogłębionym poznaniu siebie (RFIS 59). Wprowadzenie w życie modlitwy, zasłuchanie w Słowo Boże, częściowe uczestniczenie w modlitwie Kościoła poprzez Liturgię Godzin, pogłębienie znajomości doktryny katolickiej będzie stanowić płaszczyznę rozwoju więzi z Chrystusem oraz spokojne i pełne wsparcia poznawanie samego siebie (kan. $244 \S 1$ ). Sprzyjać temu będzie właściwe miejsce oddzielone od wspólnoty wyższego seminarium duchownego (RFIS 60).

Ustawodawca w kan. $241 \S 1$ wskazuje, iż do seminarium mają być przyjęci jedynie ci, którzy wydają się być zdolni do podjęcia świętej posługi, mając ku temu właściwe przymioty. W kontekście RFIS kandydat będzie

${ }^{19}$ Congregazione per il Clero, Istruzione Il presbitero, pastore e guida della comunità parrocchiale (4.08.2002), Libreria Editrice Vaticana, Città del Vaticano 2002; tekst polski: Kongregacja ds. Duchowieństwa, Kapłan, pasterz i przewodnik wspólnoty parafialnej, Wydawnictwo Diecezji Tarnowskiej Biblos, Tarnów 2002. 
zdatny do podjęcia formacji, jeśli jego stan zdrowia fizycznego i psychicznego będzie zgodny z kryteriami Kościoła. Należy wziąć pod uwagę, czy kandydat jest wolny od chorób typu alkoholizm, czy nie cierpi na celiakię lub czy jego sfera tożsamości i seksualności jest właściwie wykształcona zgodnie z nauczaniem doktryny katolickiej w tej materii.

Nie należy przyjmować do wyższego seminarium duchownego osób, które przejawiają $\mathrm{w}$ sferze psychicznej jakąkolwiek patologię (RFIS 65). Formatorzy mają prawo rozeznania stanu psychicznego alumna poprzez specjalistyczne badania (także w dalszych etapach formacji ${ }^{20}$. Od odpowiedzialnych za formację kapłańską wymaga się obiektywnej i sprawdzonej wiedzy na temat kandydata (kan. 1051). Weryfikacja jego stanu psychicznego przebiega $\mathrm{z}$ zachowaniem należytego szacunku (kan. 220). Kandydat powinien wyrazić zgodę na piśmie (RFIS 194). Ponadto kandydat może poprosić o badanie wykonywane przez jednego ze specjalistów zaproponowanych przez formatorów lub przez wskazanego przez siebie za zgodą formatorów (OCPF 12). Wyniki badania biegły przedstawia kandydatowi, który podlegał weryfikacji psychologicznej bądź psychiatrycznej. Prawo do informacji na ten temat mają także osoby upoważnione ze względu na wykonywany urząd. Są nimi: biskup, rektor oraz kierownik duchowy (RFIS 195).

Obowiązkiem kandydata do wyższego seminarium duchownego jest także przedstawienie świadectwa chrztu i bierzmowania (kan. $241 \S 2$ ). Jest to wymóg, by zweryfikować zdatność kandydata do święceń, tak co do ważności, jak i ich godziwości. Ustawodawstwo partykularne określa dokumenty dodatkowe wymagane przy przyjęciu do seminarium duchownego (kan. $241 \S 2$ ).

Decyzja o przyjęciu kandydata do seminarium jest uzależniona także od jego kondycji moralnej. RFIS uwrażliwia odpowiedzialnych za formację do kapłaństwa, aby weryfikacja kandydatów była przeprowadzona ze szczególną ostrożnością, mającą na celu ochronę Ludu Bożego, tak w osobie wiernych świeckich, jak i stanu kapłańskiego. Nie można zatem przyjmować do seminarium osób, które dopuściły się przestępstw wobec małoletnich, osób dorosłych - słabych i bezbronnych (RFIS 202).

${ }^{20}$ Congregazione per L'Educazione Cattolica, Orientamenti per l'utilizzo delle competenze psicologiche nell'ammissione e nella formazione dei candidati al sacerdozio (29.06.2008) [dalej cyt.: OCPF], http://www.vatican.va/roman_curia/congregations/ccathe duc/documents/rc_con_ccatheduc_doc_20080628_orientamenti_it.html [dostęp: 24.05. 2019], nr 12. 
Uwaga przełożonych powinna być także skierowana na tych, którzy proszą o przyjęcie, wcześniej zaś zostali wydaleni z seminarium duchownego lub instytutu zakonnego (kan. $241 \S 3$ ). Często będzie to dotyczyć sytuacji delikatnych, wymagających rzetelnego sprawdzenia [Selejdak 2017, 129]. Taki kandydat w prośbie o przyjęcie musi przedstawić swoją sytuację, zawierając w opisie informacje istotne, dotyczące drogi życiowej oraz motywów, dla których został usunięty z seminarium lub musiał opuścić instytut. Rektor seminarium ma obowiązek uzyskania właściwej dokumentacji, w tym także dokumentów dotyczących poprzedniej weryfikacji psychologicznej (RFIS 198).

Kolejnym etapem jest czas studiów filozoficznych, zwany „etapem bycia uczniem”. Alumni mają w tym czasie uczyć się naśladować Chrystusa i coraz bardziej podejmować w swym sercu zamiar głoszenia Ewangelii. Formatorzy mają dopomóc w tym, by alumn zakorzenił się w kroczeniu za Chrystusem (RFIS 61-62). W tym etapie przeważa zaangażowanie w rozwój ludzki powiązany harmonijnie $\mathrm{z}$ wymiarem duchowym. Rozwój osoby w łonie wspólnoty seminaryjnej ma bardzo dobre warunki. Alumn objęty właściwym oddziaływaniem może zmierzyć się ze sobą, doceniając swoje talenty i pozytywne cechy oraz dostrzegając to wszystko, co w nim dotknięte jest słabością. Współpracując z łaską może wzrastać, by podjąć obowiązki stanu duchownego ${ }^{21}$.

„Etap bycia uczniem” powinien trwać nie mniej niż dwa lata. Na zakończenie studiów filozoficznych, gdy seminarzysta osiągnie odpowiednią wolność i wewnętrzną dojrzałość, będzie mógł zostać dopuszczony do kandydatury (RFIS 66-67). Właściwy przełożony może tego dokonać, jeśli seminarzysta złoży napisaną i podpisaną przez siebie prośbę. Akceptacja prośby przez władzę powinna być stwierdzona na piśmie (kan. 1034 § 1). Liturgiczny obrzęd dopuszczenia do święceń oznacza publiczne wyrażenie woli kandydata, by swoje życie poświęcić Kościołowi i kapłańskiej służbie [Pastuszko 2008, 357]. Kościół zaś wybiera go i umożliwia przygotowanie do święceńn ${ }^{22}$.

\footnotetext{
${ }^{21}$ Congregazione per il Clero, Intervista al Cardinale Beniamino Stella, Prefetto della Congregazione per il Clero (22.02.2019), http://www.clerus.va/content/dam/clerus/ Dox/Intervista\%20Cardinale\%20Stella.pdf [dostęp: 24.05.2019].

${ }^{22}$ Konferencja Episkopatu Polski, Zmodyfikowana instrukcja w sprawie posług oraz święceń udzielanych w seminariach duchownych (4.05.1982), w: Prawo sakramentów. Wybór źródeł Kościoła łacińskiego, s. 861-65, pkt 28.
} 
Pragnienie ofiarowania swojego życia Bogu i Kościołowi na drodze kapłańskiego życia, wyrażone w akcie kandydatury, stanowi przejście do kolejnego etapu formacji początkowej, którym są studia teologiczne, inaczej „etap upodabniania się do Chrystusa” (RFIS 68). Etap ten jest dodatkowo zaznaczony przez obłóczyny, które zwyczajowo mają miejsce na początku studiów teologicznych [Puchalski 2018, 424]. Formacja duchowa na tym etapie ma przebiegać w kierunku budowania jeszcze głębszej więzi z Chrystusem. Kandydaci do kapłaństwa powinni starać się żyć według cnót kardynalnych, teologalnych oraz rad ewangelicznych (RFIS 69-71).

Ważnym zagadnieniem na tym etapie formacji (a także do końca życia duchownych) jest dojrzałość osobowa, zwłaszcza w obszarze emocjonalności i seksualności. Duchowni otrzymują w swym powołaniu dar i zadanie celibatu, aby w ten sposób poświęcić się dla innych (RFIS 67). Celibat jest świadectwem i znakiem życia według prymatu wiary [Kantor 2011, 68]. Formacja w tym zakresie powinna umacniać rozwój seminarzysty w wymiarze ludzkim i duchowym. Wraz z osiągnięciem dojrzałości ludzkiej, będzie mógł wybrać w sposób spokojny, przemyślany i dobrowolny tak poważne zobowiązanie, jakim jest bezżennośćc ${ }^{23}$. Tak poprowadzona droga formacji przygotuje kandydata, po uprzednim dojrzałym i wolnym rozeznaniu, do publicznego zobowiązania się do celibatu (kan. 1037). Przygotowanie do przyjęcia zobowiązania do celibatu, jak i sposób prawny wyrażenia woli, muszą być właściwie przeprowadzone, aby uniknąć możliwej nieważności tegoż zobowiązania (kan. 125-126). Jest to zagadnienie wielkiej wagi. Istnieje bowiem, przynajmniej teoretycznie, możliwość stwierdzenia nieważności zobowiązania do celibatu, jednak w takich sytuacjach stosuje się procedurę dyspensy od celibatu [Skonieczny 2018, 76-77].

„Etap upodabniania się do Chrystusa” kształtuje postawę miłości do Kościoła (kan $245 \S 2$; RFIS 71). Jej skutecznym wyrazem są konkretne działania, dlatego też w cyklu formacyjnym przewiduje się udzielenie posług lektoratu, a w dalszej kolejności akolitatu (kan. 1035; RIFS 72). Lektor ma w zgromadzeniu liturgicznym funkcję odczytywania Pisma Świętego, akolita zaś ma wspierać diakona i służyć kapłanowi w trakcie liturgii,

${ }^{23}$ Paulus PP. VI, Litterae encyclicae de caelibatu Sacerdotalis caelibatus (24.06. 1967), AAS 59 (1967), s. 657-97; tekst polski w: Nauczanie Kościoła Katolickiego wersja 1.1 - program komputerowy, Wydawnictwo „M”, Kraków 2003, nr 69. 
jest również nadzwyczajnym szafarzem Komunii Świętej24. Stopniowe wprowadzanie alumnów w posługi będzie umacniać w nich zażyłość z Chrystusem. Stanowi to wielki obowiązek [Słowikowska 2014, 177]. W takiej postawie seminarzysta powinien dojrzale ocenić, czy subiektywne przekonanie o powołaniu do kapłaństwa urzędowego jest prawdziwe. Jego ocena musi zgadzać się z opinią Kościoła. Jeśli u kandydata nie rozpozna się powołania, albo stwierdzi się brak zaangażowania w to powołanie, należy przerwać jego drogę do kapłaństwa (kan 241 § 1 i 3; RIFS 72). Na koniec tego etapu, jeśli powołanie zostanie rozpoznane i przyjęte, kandydat powinien prosić o udzielenie święceń (kan. 265; RIFS 73).

Ostatnim etapem formacji początkowej jest „etap pastoralny (albo syntezy powołaniowej)". Po święceniach diakonatu duchowny jest stopniowo włączany $\mathrm{w}$ duszpasterstwo, otrzymuje właściwe towarzyszenie formatorów. Szczególne zadanie towarzyszenia spoczywa również na proboszczu, do którego diakon zostanie skierowany (RFIS 75). Czas tak zwanej praktyki należy do decyzji ordynariusza. Należy jednak zachować odstęp sześciu miesięcy między diakonatem a prezbiteratem, z zachowaniem dyspozycji ustawodawcy co do wieku mających przyjąć święcenia (kan. 1031 § 1, kan. 1032 § 2; RIFS 76). Ponadto ustawodawca określa wiek kandydatów do święceń - w przypadku diakonów przejściowych jest to ukończenie 23 roku życia, w przypadku prezbiteratu ukończone 25 lat. Konferencja biskupów może ustalić wyższy wiek do prezbiteratu, biskup zaś może udzielić dyspensy od wymaganego prawem powszechnym wieku, jednak nie może być to dyspensa od okresu przekraczającego jeden rok (kan. 1031 § 1-4).

Organizacja studiów wpisuje się w wymiar intelektualny formacji do kapłaństwa (RFIS 153). Przedmioty wykładane w seminarium mają być właściwie zintegrowane (kan. $254 \S 1$; RFIS 153). Przypomina się o tym, że całość studiów powinna trwać sześć lat (kan 250; RFIS 154). Poszczególne konferencje biskupów w dostosowaniu krajowym mają sporządzić wykaz przedmiotów przewidzianych na każdym z etapów formacji (RFIS 154). Dokument Kongregacji ds. Duchowieństwa określa zakres przedmiotów dla poszczególnych etapów: „etap propedeutyczny” - wprowadzenie do lektury Pisma Świętego, studium Katechizmu Kościoła Katolickiego, wprowadzenie do lektury dokumentów Soboru Watykańskiego II, elementy

${ }^{24}$ Tenże, Motu proprio Ministeria queadam (15.08.1972), AAS 64 (1972), s. 52934; tekst polski w: Prawo sakramentów. Wybór źródeł Kościoła łacińskiego, s. 835-39, $\mathrm{nr}$ V-VI. 
duchowości kapłańskiej, elementy historii Kościoła, hagiografia, kultura, psychologia (RFIS 157); „etap bycia uczniem” - wykład filozofii systematycznej, metafizyka, historia filozofii, antropologia filozoficzna, logika, epistemologia, socjologia, pedagogika, psychologia (RFIS 159-163); „etap upodabniania się do Chrystusa" - studium Pisma Świętego, kurs języków biblijnych, liturgika, teologia dogmatyczna, teologia fundamentalna, teologia moralna, teologia pastoralna, misjologia, katolicka nauka społeczna, historia Kościoła, ekumenizm, prawo kanoniczne, studium homiletyczne, kurs co do praktyki spowiednictwa, sztuka sakralna, komunikacja społeczna (RFIS 166-184).

Po zakończeniu studiów, rozeznaniu osobistym seminarzysty i ocenie Kościoła co do zdatności kandydata do święceń, można przystąpić do realizacji procedury bezpośrednio poprzedzającej udzielenie święceń. W kan. $1050,1^{\circ}-3^{\circ}$ ustawodawca stanowi, że należy zgromadzić odpowiednią dokumentację: zaświadczenie o odbytych studiach (kan. 1032 § 1-3), wraz ze świadectwem ze szkoły średniej [Pastuszko 2008, 529], świadectwo chrztu i bierzmowania, a w przypadku przystępujących do prezbiteratu dokument potwierdzający przyjęcie diakonatu, potwierdzenie przyjęcia lektoratu i akolitatu (kan. 1035), stwierdzenie złożenia oświadczenia o świadomym i dobrowolnym przystąpieniu do święceń, z przyjęciem wszystkich wiążących obowiązków (zwłaszcza celibatu) [Jakubiak 2013, 19] wraz z prośbą o święcenia. Dokumentacja powinna obejmować także te elementy które wyliczyła Kongregacja ds. Kultu Bożego i Dyscypliny Sakramentów ${ }^{25}$.

Celem dokładnego zbadania zdatności koniecznie należy przeprowadzić skrutynia (kan. 1051; RFIS 204). Mają one zawierać gruntowną ocenę kandydata $\mathrm{w}$ odniesieniu do żądanych przez ustawodawcę przymiotów i uwarunkowań kandydatów do święceń [Janczewski 2014, 239]. Biskup diecezjalny lub kompetentny wyższy przełożony mogą zarządzić dodatkowe badanie (kan. 1051, $2^{\circ}$ ). Po dokładnym przeprowadzeniu badania zdatności kandydata, potwierdzeniu odbycia pięciodniowych rekolekcji (kan. 1039), kompetentny przełożony wystawia dymisorie do święceń (kan. 1020). Nie można ich wystawić bez zebrania dokumentów, o których jest mowa w kan. 1050-1051 [Pastuszko 2000, 246]. Ponadto kompetentna władza powinna być przekonana o możliwości udzielenia święceń [Skorupa

${ }^{25}$ Congregazione per il Culto Divino e la Disciplina dei Sacramenti, Lettera circolare Entre las más delicada (10.11.1997), „Notitiae” 33 (1997), s. 495-506. 
2011, 88], co wyrazi stosownym dekretem (RFIS 210). Jeśli diakon nie zostanie dopuszczony do święceń, może wnieść rekurs (kan. 1030). Może to uczynić, jeśli czuje się pokrzywdzony decyzją biskupa [Romanko 2016, 160].

Po święceniach należy sporządzić odpowiednie świadectwo przechowywane w kurii (kan. $1053 \S 1$ ) oraz wydać zaświadczenie o święceniach (kan. 1053 § 2). Święcenia należy także wpisać w akcie chrztu wyświęconego (kan. 1054).

\section{ZAKOŃCZENIE}

Kodeks Prawa Kanonicznego z 1983 r. oraz Ratio fundamentalis institutionis sacerdotalis zawierają normy, które mają na celu właściwe ukierunkowanie formacji kandydatów do kapłaństwa. Przepisy wydane przez ustawodawcę stanowią skuteczne narzędzie oddane do dyspozycji biskupów oraz formatorów działających w imieniu biskupa lub innych kompetentnych przełożonych. Dostosowane do współczesnych warunków i okoliczności działania Kościoła są dla odpowiedzialnych za dzieło powołań drogowskazem i kryterium zdatności do święceń.

\section{PIŚMIENNICTWO}

Adamczyk, Jerzy. 2013. „Choroba celakii w odniesieniu do sakramentu święceń.” Annales Canonici 9:75-92.

Gerosa, Libero. 1999. Prawo Kościoła. Poznań: Pallottinum.

Gosiewski, Radosław. 2017. „Prawo do swobodnego wyboru stanu życia.” W Obowiązki i prawa wiernych w świetle Kodeksu Prawa Kanonicznego, red. Marek Saj, 219-48. Warszawa: Scriptum.

Janczewski, Zbigniew. 2014. „Święcenia.” W Wielka Encyklopedia Prawa. T. 2: Prawo kanoniczne, red. Grzegorz Leszczyński, 236-39. Warszawa: Fundacja „Ubi societas, ibi ius".

Jakubiak, Tomasz. 2013. „Procedury do przyjęcia święceń diakonatu i prezbiteratu.” Prawo Kanoniczne 56, nr 3:3-34.

Kantor, Robert. 2011. Rola i zadania wikariusza parafialnego. Studium kanonicznopastoralne. Tarnów: Wydawnictwo Diecezji Tarnowskiej Biblos.

Krukowski, Józef. 2011. „Święcenia.” W Komentarz do Kodeksu Prawa Kanonicznego. T. III/2: Uświęcające zadanie Kościoła. Część I. Sakramenty. Część II. Pozostałe akty kultu Bożego. Część III. Miejsca i czasy święte, red. Józef Krukowski, 205-49. Poznań: Pallottinum.

Pastuszko, Marian. 2000. „Szafarz święceń (kanony 1012-1023).” Prawo Kanoniczne 43 , nr 3-4:117-251. 
Pastuszko, Marian. 2001. „Przyjmujący święcenia (kanony 1024-1025).” Prawo Kanoniczne 44, nr 1-2:71-110.

Pastuszko, Marian. 2008. Sakrament święceń (kanony 1008-1054). Kielce: Jedność.

Pawlina, Krzysztof. 2008. „Kapłani dla nowej generacji młodzieży.” Studia Salvatoriana Polonica 2:13-23.

Puchalski, Grzegorz. 2018. „Etapy formacji początkowej wedłu nowego Ratio Fundamentalis Institutionis Sacerdotalis w kontekście formacji w Wyższych Seminariach Duchownych w Polsce." Studia Elbląskie 19:417-29.

Romanko, Agnieszka. 2016. Mediacja w sprawach administracyjnych w prawie kanonicznym $i$ w prawie polskim. Lublin: Towarzystwo Naukowe KUL.

Selejdak, Ryszard. 2017. „Formacja kandydatów do kapłaństwa w świetle nowego Ratio Fundamentalis Institutionis Sacerdotalis.” Collectanea Theologica 87, nr 3:97-132.

Skonieczny, Piotr. 2018. Dyspensa od celibatu kościelnego. Kraków: Wydawnictwo Naukowe UPJPII.

Skorupa, Ambroży. 2011. „Kwalifikacje wymagane od kandydatów do święceń.” Studia Salvatoriana Polonica 5:87-98.

Słowikowska, Anna. 2014. Uczestnictwo wiernych świeckich w liturgii Kościoła łacińskiego. Studium kanoniczne. Lublin: Towarzystwo Naukowe KUL.

Stokłosa, Marek. 2015. Utrata stanu duchownego. Warszawa: Wydawnictwo UKSW.

Zdatność do święceń i przygotowanie do kapłaństwa

według Kodeksu Prawa Kanonicznego z 1983 roku

i Ratio fundamentalis institutionis sacerdotalis z 2016 roku

Streszczenie

Problematyka podjęta $\mathrm{w}$ artykule dotyczy sakramentu święceń, a ściśle przygotowania do święceń według wymogów Kodeksu Prawa Kanonicznego z 1983 r. i nowego Ratio fundamentalis institutionis sacerdotalis, które zostało wydane w 2016 r. W pierwszej części artykułu zaprezentowano kanony odnoszące się do wymogów ważności święceń oraz ich godziwości. Druga część jest prezentacją norm zawartych w Ratio fundamentalis. W artykule przytoczono także inne, obowiązujące normy prawa, które są przejawem troski Kościoła o właściwą formację przyszłych kapłanów.

Słowa kluczowe: święcenia; celibat; nieprawidłowość; formacja kapłańska

Suitability for Sacred Ordination and Preparation Process for the Priesthood According to the 1983 Code of Canon Law and Ratio fundamentalis institutionis sacerdotalis of 2016

\section{Summary}

The study focuses on the sacrament of Holy Orders, in particular the preparation process to sacred ordination according to the requirements of the 1983 Code of Canon Law and the new Ratio fundamentalis institutionis sacerdotalis published in 2016. Canons relating to the prerequisites of the validity of sacred ordination and their 
fairness were presented in part one of the article. The norms included in Ratio fundamentalis were introduced in part two. Other binding rules of law which are the object of Church concern of proper formation of priests-to-be were also mentioned in the article.

Key words: sacred ordination; celibacy; irregularity; priestly formation

Information about Author: Rev. PIOTR FIAŁEK, J.C.L. - Ph.D. student, Department of Church Procedural Law, Marriage Law and Penal Law and the Eastern Catholic Churches, Institute of Canon Law, Faculty of Law, Canon Law and Administration at the John Paul II Catholic University of Lublin; ul. Brata Alberta 2a, 14-202 Iława, Poland; e-mail: kspiotrf@gmail.com; https://orcid.org/0000-0001-5647-8810 